\title{
ШАХОВІ МОДЕЛІ СТОСУНКІВ В СУСПІЛЬСТВІ І ЇХ ВПЛИВ НА ФОРМУВАННЯ СВІТОГЛЯДУ ІНДИВІДА
}

\author{
О. С. Синьов \\ Здобувач наукового ступеню кандидата наук \\ Президент громадської організації Центр Громадських Ініціатив «Східна зірка»
}

Роль шахів у формуванні світогляду людини безперечно велика, попри те, що їх походження — навіть не гіпотеза, оскільки гіпотезі потрібні хоч якісь доказові підстави, а про походження шахів говорять тільки древні літературні джерела (легенди). Класичні шахи як засіб виховання людини мало вивчені сучасною наукою. Імовірно, шахи є мікро моделлю людських відносин і устрою світу. У вигляді шахової гри вона існує близько 2000 років. Саме тому там є і рядові, і кіннота, і війська, і фортеці, і король, і королева. Навіть зараз усі іiі складові $є$ присутніми у бутті, що оточує нас. Але не усі елементи буття $є$ в шахах, тому нам цікаво, наскільки шахи адекватні світу?

Поняття симбіозу узяте нами з біології для опису процесів в суспільстві внаслідок того, що видима певна схожість між взаємовідносинами біологічних об’єктів і соціальних. Під соціальними стосунками розумітимемо усі їх різновиди від міжособистісних до взаємодій великих груп (народів). Використовуючи метод аналогії, застосуємо концепцію симбіозу для опису ситуацій, що виникають в процесі гри в «Руські шахмати». I проведемо порівняльний аналіз Руських і класичних шахів на предмет формування системи цінностей у гравців.

Потрібно сказати, що авторська назва шахової гри, в котру грають три гравці, на українській мові має назву «Руські шахмати». Не плутати 3 некоректним перекладом як «Російські шахи». В нашій статті ми свідомо, для простоти порозуміння будемо називати і класичні і Руські однаково шахи. Хоча слово «шахматы» має походження з санскриту і перекладається як шах — король, мат - смерть. Назва гри - Смерть королю. В українському перекладі загубили половину слова, а саме «мат» - смерть. I тому на сьогодні ми маємо хибне слово - шахи. Також можна зустріти не вірний переклад з російської мови на українську слова «Русские». Найчастіше перекладають як «російські», але це геть не вірно, тому що Росія це держава і «російські» означає належність до держави, в той час як «руські» означає належність до культурного шару. Належність України до цього культурного шару дуже велика, хоча загалом не дуже усвідомлюється. Як приклад, можна навести назви міст України від заходу до сходу (Рава-Руська, Руська Лозова, Руські Тішки и т. п.)

Симбіоз (у перекладі з грецького «спільне життя») - форма тісних взаємовідносин між організмами різних видів або, більше узагальнено, між різними елементами системи, при якій хоч би один з них дістає для себе користь (https://ru.wikipedia.org/wiki/Симбіоз). Термін «симбіоз» прийшов з біологіï, але знайшов застосування і у філософії, і в соціології, і в педагогіці, і в етнографії, а також ряді інших наукових дисциплін. Взаємо вигідний, обов' язковий вид симбіозу називають мутуалізмом. Стосунки, корисні одному, але байдужі іншому симбіонту, називають коменсалізмом. Стосунки, шкідливі одному, але байдужі іншому називають аменсалізмом. А кооперацією називають необов'язкові взаємовигідні стосунки. Форма симбіозу, при якій один організм (паразит) використовує інший (хазяїн) як джерела живлення або/і місця існування, називається паразитизмом.

Основи вчення про взаємодопомогу, як окремий випадок симбіозу, заклали в другій половині XIX ст. незалежно один від одного російський філософ П.А. Кропоткин і зоолог, засновник Петербурзького суспільства дослідників природи, доктор філософії К.Ф. Кесслер, а також німецький ботанік і мікробіолог Г. А. де Бари, що запропонував терміни «симбіоз» і «мутуалізм». На думку Кропоткина, етика $\epsilon$ «кращою зброєю у великій боротьбі за існування, яка постійно ведеться тваринами проти клімату, повеней, бурь, буранів, морозу і т. п». [1, с. 14]. Петро Кропоткин доводить, що в природі лише з першого погляду перемагає хижак, що насправді в природі «безліч видів безумовно слабких», які набагато краще за хижаків «досягають успіху у боротьбі за існування, і завдяки властивій їм товариськості і взаємному захисту вони навіть витісняють суперників і ворогів, незрівнянно краще їх озброєних. Це мурашки, бджоли, голуби, гризуни, олені, i так далі» [1, с. 16]. Практика взаємодопомоги в природі завжди веде до прогресивного розвитку. Взаємодопомога дає «такі переваги видам тварин, що практикують iї, що абсолютно змінює співвідношення сил не на користь хижаків» [2, с. 264]. Таким чином, симбіоз має на увазі з'єднання, спільне існування, при яких хоч би одна із сторін отримує вигоду.

Конфронтація - навпаки, поняття про стосунки, що містять протиборство, протиставлення, зіткнення соціальних систем, класових інтересів, переконань. Конфронтація породжує конфлікт. 3 різновидів конфлікту нас цікавить в першу чергу соціальний конфлікт, коли людині кидає виклик іншій людині, групі осіб або суспільству. Крайній прояв конфлікту — це знищення однісї із сторін конфлікту іншої його сторони [3].

Розглянемо і порівняємо взаємовідносини у двох модельованих у шахах співтовариствах. Одно складається 3 двох гравців класичної шахової партії, а інше складається з трьох гравців, що грають в Руські шахи [4]. Шахова партія має на увазі тимчасове об'єднання гравців в колектив, який за умовами гри вимушений 
взаємодіяти в різних варіантах. Гравців ми розглядатимемо як тимчасове співтовариство, в якому проявляються взаємодії, що цікавлять нас. Шахи виступають у нас як ініціатор і регулятор міжособистісних стосунків.

Які варіанти взаємодії представляє нам гра в класичні шахи? Суперництво, боротьба, конфронтація, прагнення до домінування, і таке інше. Активно практикуючи гру в шахи один на один, ми тренуємо і виховуємо в собі вище перелічені якості. Повторюючи з разу в раз певні моделі поведінки, ми формуємо у свідомості стійкі патерни, які неусвідомлено проявляться в нашій повсякденній діяльності. С такий вислів: «Посієш вчинок - пожнеш звичку, посієш звичку - пожнеш характер, посієш характер - пожнеш долю». Звичка друга натура, і шахісти виховують в собі борців, націлених на суперництво і конфронтацію. Нічого іншого правила класичних шахів і не припускають, навпаки, заохочують конфліктність. Формований в ігровому процесі стереотип поведінки людини, спрямований на затвердження власної переваги у будь-яких умовах, стає поведінковою нормою. Звідси витікає, зокрема, питання про те, з якого віку має сенс залучати дітей до вивчення шахів і участі в шахових заходах. Якщо між ними буде з дитинства боротьба, суперництво, протистояння і тому подібні стосунки, та до того ж посилені слов'янським максималізмом, то кому від цього буде користь? Для кооперації, колективності і народу громадського типу усе це украй погано.

Слов'яни історично були общинниками, хоча треба помітити, що з кожним роком ця наша культурна особливість все більше розмивається індивідуалізмом споживчого суспільства [5]. Руйнуючи культурні форми поведінки, що склалася за віки існування етносу, минулі випробування часом, які зіграли найважливішу роль для його виживання в складних умовах (природних, історичних і т. п.), ми наражаємо на небезпеку існування цього етносу в майбутньому. Неусвідомлене копіювання чужих моделей поведінки може привести нас до поглинання іншим культурним полем і виродженню власного. Результат такої діяльності називається «Втрата орієнтації» [6]. Змінений світогляд i, як наслідок, правила взаємовідносин можуть якщо не знищити громадські народності, то багато в чому скоротити їх чисельність. Метафоричним прикладом можуть бути способи життя риби і птаха. Самий кращий підводний палац виявиться могилою для солов’я і його блискучі здібності співати в сторонньому середовищі не реалізовуватимуться. Проведемо аналогію з фізичними видами спорту. Шахи теж відносяться до спорту, хоч і до інтелектуального, але підхід до фізичних навантажень аналогічний підходу до інтелектуальних навантажень. У спорті є ранжирування, категорії, наприклад, вагові категорії у штангістів. $Є$ штангісти легкої ваги, є важкоатлети, і ніхто не вимагає від штангіста або боксера легкої ваги змагатися з важкоатлетом або навантажити легкоатлета нормативами важкоатлета. Жінці не дозволяється піднімати більше 25 кг, щоб вона не надірвалася. У шахах однакова інтелектуальна «вага» дається і дітям, і жінкам, і дорослим чоловікам, і що з ними буде - таке питання навіть не ставиться. У шахах ми зустрічаємо нерозуміння суті дії гри і їі наслідків на людину, абсолютне нерозуміння дій інтелектуальної ваги, ніякого ранжирування, ніякого наукового осмислення процесу, що відбувається. I діти, і дорослі, і майстри, і початківці, усі грають однією вагою. Тобто їм дається однаковий інтелектуальний вантаж повноцінних шахів.

Який висновок з вищесказаного? Більшого егоїста, ніж шахіст, не існує. У самих правилах гри закладена певна філософія поведінки (боротьби і навіть «вбивства»), яка згодом екстраполюється на повсякденну соціальну практику. Відбувається виродження духовності і людяності. Правилами гри не передбачені такі людські якості, як співчуття, дружба, взаємовиручка і тому подібне. Роз'єднане суспільство, наслідуючи принципи паразитизму і індивідуалізму, не здатне перейти до вищого ступеня розвитку. Як наслідок, ми бачимо прояв негативних поведінкових чинників в людському суспільстві від конкуренції і розгулу злочинності до локальних і світових воєн. Сьогодні, маючи у своїх руках що найпотужніший вигляд озброєння, таке як ядерне, ми стаємо небезпечні самі для себе. Узагальнюючи цілий букет небезпек, що підстерігають людство на його шляху розвитку, глобальне наукове і політичне співтовариство займаються розробкою нової парадигми мислення [7]. Багато учених вважають, що третє тисячоліття або буде духовним, або його не буде взагалі, що настав час перейти з епохи варварства до епохи цивілізації [8].

Для того, щоб змінити світоглядну картину, що склалася за тисячоліття, і характер стосунків в людському суспільстві, треба у свідомість людей плавно вводити разом із вже існуючим розділовим сполучником «або» єднальний сполучник «і». Природно, відразу це зробити не вдасться в силу великих інерційних процесів в колективній свідомості. Але робити треба вже зараз. Шахове поле з фігурами звичайно, обмежено, як і планета Земля з iі ресурсами. Знаходячись в умовах однієї замкнутої системи, ми повинні навчитися співпрацювати один з одним - інакше вичерпання ресурсу на конфлікти або глобальний конфлікт обіцяють нам невтішні перспективи.

Костянтин Едуардович Ціолковський у своїй повісті «Пригоди атома» запропонував варіант зміни суспільного устрою від капіталістичного (індивідуалістичного) до комуністичного (колективного, общинного) без обтяження і грубої ломки людей і держав [9]. Рішенню такої задачі можуть сприяти модернізовані шахи, що нещодавно з'явилися на пострадянському просторі. Ці нові шахи називаються «Руські шахмати» або тригональні. Число гравців - три людини одночасно. При грі утрьох у нас непомітно серед сталих стереотипів конфронтації з'являється новий стереотип - співпраця. Не лише ти або я, але і ти і я. Це новий тип раціо- 
нального мислення, в основі якого лежить трійка, або непарне число. Якщо в класичних шахах стоїть завдання убити супротивника і в процесі гри гравці діляться на два, тобто один вбиває іншого, то в Руських шахах із-за особливості непарного числа гравців завжди з'являється можливість чинити опір сильнішому супротивникові двом іншим слабкішим гравцям шляхом союзу або кооперації. Природно, що до розуміння взаємо вигідності тимчасового союзу проти сильнішого гравця вони приходять шляхом аналізу поточної ситуації на ігровому полі. Таким чином через гру у свідомість входить інструмент для взаємодії, що дозволяє здійснювати симбіоз в різних його варіантах. Ситуаціі, що виникають при грі утрьох, змушують нас до симбіозу. Мало того, якщо ми хочемо мати успіх у вигляді перемоги в партії, то ця консолідація обов'язково має бути. Вона, звичайно, тимчасова i залежить від ходу гри. Але такий варіант стосунків як співпраця, що практикується в процесі гри, вже закріплюється у свідомості. Повторюючись багаторазово в практиці гри, симбіотична модель поведінки 3 часом перейде в підсвідомість і проявлятиметься в повсякденній діяльності гравців. Ще один плюс Руських шахів це можливість створювати свої правила гри. Як інструмент моделювання, вони дуже рухливі, гнучкі і пристосовані під опис будь-яких ситуацій. На сьогодні налічують приблизно 200 варіантів правил гри в Руські шахи, і це незважаючи на їх молодий вік.

Очевидним є висновок про більшу кількість різноманітності характерів стосунків між учасниками тимчасового співтовариства, яким є колектив, що сидить за однією дошкою. Різний характер стосунків від контрактації до співдружності відсовує убік формулу, в якій говориться, що життя - це боротьба. Не обов’язково це боротьба. У житті багато всього окрім боротьби. Мати, наприклад, зі своєю дитиною не бореться, як $з$ супротивником, на знищення. Можлива боротьба з його шкідливими схильностями, із слабкостями фізичними і душевними, але ця боротьба має інший характер і мету зробити дитину краще. У Руських шахах створюється альтернативний варіант гри, в якому співдружність підживлює життя в усіх його проявах і формах, тоді як в класичних шахах формується установка тільки на знищення. У конфронтаційних процесах умови для розвитку практично не створюються; там немає симбіозу, немає об'єднаня, немає виходу на взаємодію, на стійкість структури і появу нового. І навпаки - в співдружності всі ці явища дають підвищення рівня системної організації і появі нових якостей, яких раніше не було у окремо взятих елементів [10].

Вивчаючи гру Руські шахи, ми знайдемо багато цікавих питань для філософів, культурологів, педагогів і психологів. Руські шахи відкривають нові можливості у формуванні світогляду людини, в якому домінує ціннісна установка на створення і збереження життя.

\section{Література}

1. Кропоткин П. А. Этика. Происхождение и развитие нравственности. М. : Полиздат, 1991. 363 с.

2. Розенберг Г. С. Конкуренція і взаємодопомога — дві сторони «медалі» взаємодії популяцій (до 175-річчя 3 дня народження Петра Олексійовича Кропоткина і 115-річчя виходу його монографії «взаємна допомога як чинник еволюції») // Ювілеї і дати. Самарський Лука: проблеми регіональної і глобальної екології. 2018. Т. 28, № 3. С. $262-$ 269.

3. Здравомыслов А. Г. Социология конфликта. Изд. 3-е, доп. и пер. М. : Аспект-прес, 1996. 317 с.

4. Малюта А. Н. Гіперкомплексні динамічні системи. Львів : Вища школа, 1989. 118 с.

5. Білорус, О. Г., Мацейко, Ю. М. Глобальна перспектива і сталий розвиток (Системні маркетологічні дослідження) : монографія. Київ : МАУП. 2005. 492 с.

6. Малюта А. Н. Система діяльності. Київ: Наукова думка, 1991. 206 с.

7. Bailey, Kenneth D. Sociology and the New Systems Theory. Toward a Theoretical Synthesis / Kenneth D. Bailey. New York : State University of New York, 1994. 372 c.

8. Бабич В. П., Могилко В. А., Онєгіна В. М. Прикладна онтологія. Харків : Вид-во «Друкарня Мадрид», 2013.364 с.

9. Ц Циолковский К. Э. Миражи будущего общественного устройства. М. : Луч, 2010. 272 с.

10. Малюта А. Н. Закономірності системного розвитку. Київ : Наукова думка, 1990. 136 с. 